Type of the Paper (Article, Review, Communication, etc.)

\title{
Emergent viral disease in alfalfa (Medicago sativa L.) plots in Cochabamba, Bolivia, A preliminary evaluation.
}

Mario Coca Morante ${ }^{1 *}$, N. Achá Molina ${ }^{2}$, A. Calani Lucas ${ }^{2}$ and R. Meneses Arce ${ }^{2}$

1 Universidad Mayor de San Simón. Facultad de Ciencias Agrícolas y Pecuarias, Departamento de Fitotecnia, Laboratorio de fitopatología 1; e-mail: m.cocamorante@umss.edu.bo

2 Universidad Mayor de San Simón. Facultad de Ciencias Agrícolas y Pecuarias. Centro de Investigación en Forrajes “La Violeta" 2; e-mail: n.acha@umss.edu.bo, r.meneses@umss.edu.bo

* Correspondence: e-mail: m.cocamorante@umss.edu.bo ;

Abstract: Alfalfa (Medicago sativa L.) is one of the most important forage crops in the world. In Bolivia it is cultivated in different parts of the High Andes and in the Interandean Valleys. The species is affected by several fungal diseases which reduce production, but before 2016 hardly any mention had been made of virus disease in the region. The aims of the present work were: 1) to describe the symptomology of this apparent viral disease, and ii) determine its effects on the yield of different alfalfa cultivars available from the CIFUMSS. In 2016, a plot was established at Tiquipaya (Dept. of Cochabamba) (altitude 2480 m) was planted with 12 alfalfa cultivars. Disease incidence values were estimated and the area under the disease progress curves (AUDPC) calculated. The disease progress curves themselves were analyzed using logit functions for polycyclic diseases, and yields were determined. Disease symptoms included deformation of the folioles, thickened veins, the presence of vein enations and papillae on the abaxial leaves, reduced plant size - all symptoms of infection apparently caused by Alfalfa Dwarf Virus. The different cultivars returned different incidence values. They also returned different apparent infection rates ranging from 0.072/day for Cóndor, to 0.113/day for Tamborada. The different cultivars returned different dry weight yields, with yields inversely related to the AUDPC. In conclusion, based on the foliar symptoms registered, the viral disease is associated with the Alfalfa Dwarf Virus. The twelve cultivars evaluated presented different incidence levels of the viral disease.

Keywords: Cultivated forage crops; plant pathology; disease incidence, emerging disease.

\section{Introduction}

Alfalfa (Medicago sativa L.) is one of the most important forage crops in the world. In Bolivia it is grown in the High Andean Puna area (3800 - 4200 m), on the Altiplano (3800 $\mathrm{m}$ ) and in the Inter Andean Valley (2000-2700 m). Alfalfa is cultivated in Bolivia with the purpose of seed production and fresh by the cattle consumption [1]. The cultivated varieties were introduced, mainly, from Peru, North America, Argentina and other countries $[2,3,4]$. Crops are generally produced from locally produced or imported seed. 
The local seed supply (part of the official seed production program) is produced by the Centro de Investigación en Forrajes (CIF-UMSS and the Forage Crop Research Centre) and the university company Semillas Forrajeras (SEFO) in inter-Andean valleys areas; small private companies provide the imported seeds of the other Latin-Americans countries.

Different alfalfa diseases have been reported in Bolivia, usually fungal in nature $[5,6]$ virus diseases were hardly ever referred to [6]. However, alfalfa is not without its viral pathogens. The most commonly reported are Alfalfa Enation Virus-AEV, Alfalfa Mosaic Virus-AMV, Bean Leaf Roll Virus (BLRV), Lucerne Transient Streak Virus-LTSV, Pea Streak Virus (PeSV), and Red Clover Vein Mosaic Virus-RCVMV [7]. In 2010, a new viral disease, named Alfalfa dwarf disease-ADD, was identified in Argentina [8,9]. Recently, reports Alfalfa Enation Virus-AEV and ADD have come from Argentina and other countries of Alfalfa crops suffering from viral disease $[9,10]$. Subsequently, ADD was identified as rhabdovirus infecting alfalfa [11] and were characterized as a new nucleorhabdorivus from alfalfa [12]. In Argentina, this viral disease decrease of up to $38 \%$ in seed production in interaction with AMV followed by ALCV [9].

Alfalfa viral diseases in Bolivia could be due to the traditional seeds introduction. According to Rojas and Gilbertson [13], with increasing global trade, the emergence of a virus in a new geographical region may be initiated by the introduction of infected plant materials (e.g., plants, propagative materials or seeds). The alfalfa seed production in Bolivia is located in the Inter Andean region as Cochabamba valley where environmental conditions favor the alfalfa cultivation but also favor the pests and diseases development and spread. At present there are no reports on alfalfa viral evaluations and its effect. But, in the Inter Andean Valleys of too plants with deformed leaves reminiscent of viral disease have been detected [5]. The aims of the present work were: 1) to describe the symptomology of this apparent viral disease, and ii) determine its effects on the matter dry yield of different alfalfa cultivars available from the CIF-UMSS.

\section{Materials and Methods}

\subsection{Experimental plot}

This work was performed in an alfalfa plot established 24th January 2010 at the Centro de Investigaciónen Forrajes "La Violeta" (CIF-UMSS), Tiquipaya (in the Central Inter Andean Valley at an altitude of $2480 \mathrm{~m}$, Province of Quillacollo, Dept. of Cochabamba), twelve alfalfa cultivars were planted, using seed provided by the above Centre's multiplication program. The random block design of the study involved four repetitions, 10 rows per experimental unit ( $8 \mathrm{~m}$ long, $0.2 \mathrm{~m}$ between rows). The sowing density was $25 \mathrm{~kg} / \mathrm{ha}$.

\subsection{Virus symptoms description}

Symptoms were recorded during the growth cycle, and are here described taking into account the indications of Samac et al. [7]. given the presence of enations, folioles were collated for stereomicroscope examination.

\subsection{Disease incidence; area under the disease progress curve}


The incidence of the suspected viral disease was determined for each cultivar on the basis of its typical symptomology between the 8th and 29th of April 2016 during the phonological phase prior to flowering, examining a $1 \mathrm{~m}^{2}$ area of each experimental unit for four times and every seven days according to the following equation: Incidence (\%) = $\frac{\text { No plantas con virosis }}{\text { No total de plantas }} x 100$ [14]. The area under disease progress curve (AUDPC) for each cultivar was then determined as follows: $\operatorname{AUDPC}=\sum\left(\frac{\mathrm{yi}+\mathrm{y} 1+1}{2}\right)(t i-1-t i)[14,16]$. The disease progress curve (CPE's) were linearized using the logistic (ln (y/1-y)) and Gompertz $(-\ln [-\ln (y)])$ functions for their analysis infection rate $[14,15,16]$.

\subsection{Matter dry Yield $\left(\right.$ t.ha $\left.a^{-1}\right)$}

Fresh and dry yields were estimated by harvesting the $1 \mathrm{~m}^{2}$ cut in the center of the experimental unit, plants were cut $5 \mathrm{~cm}$ above the ground. The entire sample was used to determine the fresh yield. Dry yield (expressed in tons by ha and by only cut) was determined using $150 \mathrm{~g}$ subsamples of the cut material; plants were placed in a fan oven at $105^{\circ} \mathrm{C}$ until a constant weight was reached (at 24-48 h).

\section{Results and discussion}

\subsection{Disease symptoms}

The disease affected the entire aerial part of the plant. The most notable symptom was the deformation and wrinkling of the folioles (Fig. $1 \mathrm{a}, \mathrm{c}$ ). On the underside of the folioles, the main and secondary veins were thickened and covered in small wart-like structures. As the plants developed, this part of the petiole became more brittle similar to enations (Fig. 1d). In general, foliole deformation was most notable towards the apical part of the plants (Fig. 1b). Plants were also small (dwarfs) (Fig. 1a) and showed slight yellowing (depending on the variety) of the nerves and folioles, vein enation and papillae on the abaxial surface of leaves. All these aerial symptoms are similar to Alfalfa Dwarf Virus-ADV, previously ADD, those described by researchers [7,9].
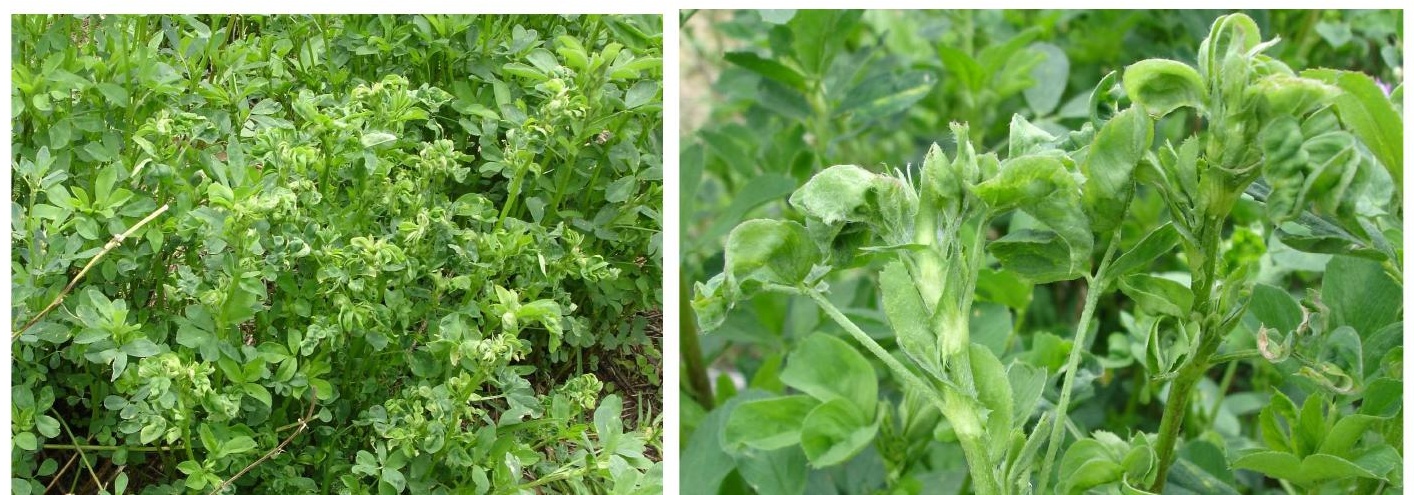


\subsection{Disease incidence and area under the disease progress curve}

The different cultivars returned different values for disease incidence (Fig. 2). In general, up until the $4^{\text {th }}$ examination (29/04/2016), the viral incidence ranged between 45 to $68 \%$ (Fig. 2a). At the beginning of foliar development after cutting, in all varieties, the disease was mild, but, at the fourth reading end (beginning of flowering), the disease reached high levels of incidence. In the disease progress curves analysis, the AUDPC estimated for cultivars show different levels of the viral disease, showing the lowest levels the Tamborada, UMSS 2001 and Altiplano cultivars; in contrast, the Africana, Gilboa and Cóndor cultivars the highest levels show (Fig. 2b).

According to the linearization analysis of the disease progress curves, all cultivars shown high determination coefficients $\left(\mathrm{R}^{2}\right)$ and different "apparent infection rates" (r) (Table 1$)$. The $\mathrm{R}^{2}$ indicates the proportion of the variation in the response $(\mathrm{y})^{7}$. According these $\mathrm{R}^{2}$ the Logistic and Gomperzt models having a similar fit and are adequately describe of all disease progress curve (Fig. 3). 


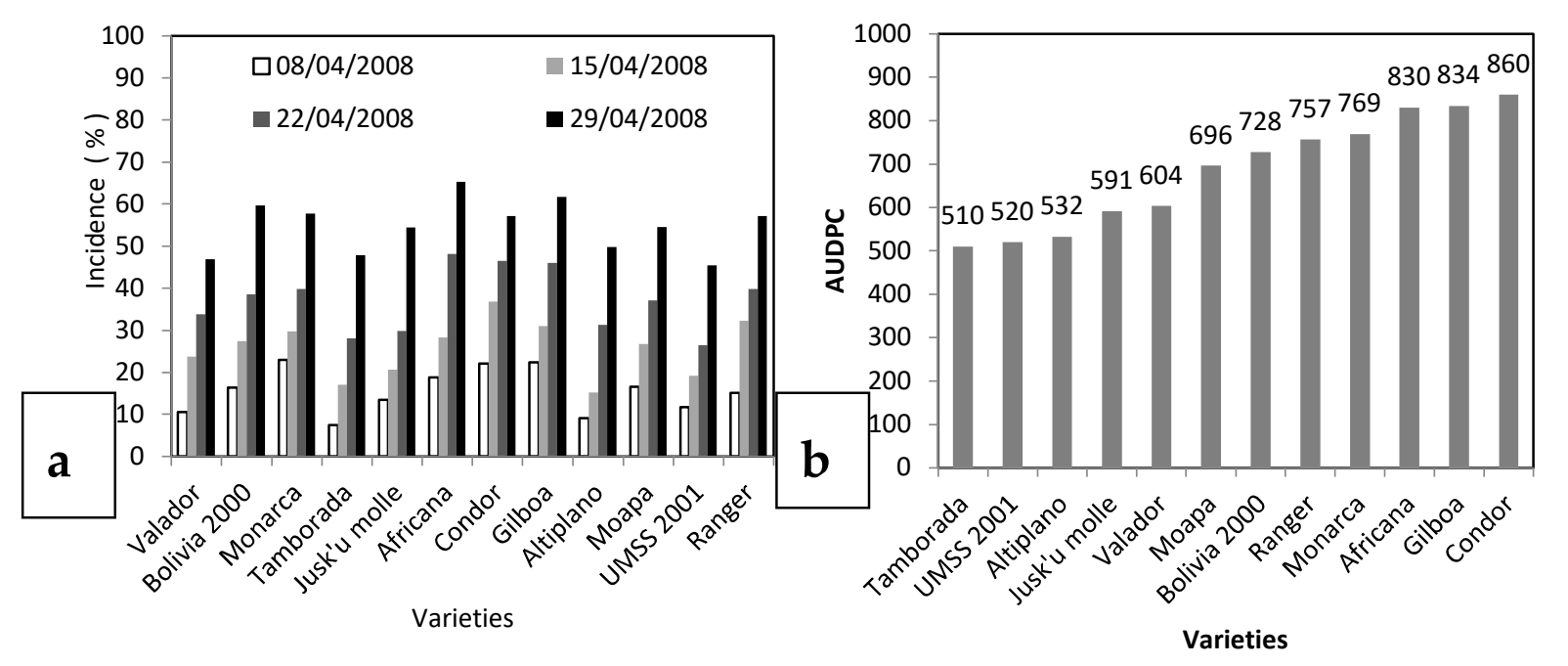

Figure 2: Alfalfa dwarf disease intensity and AUDPC values. a: Viral disease Incidence of the twelve alfalfa cultivars; b: Twelve alfalfa cultivars AUDPC. Cochabamba Valley, Bolivia.

Table 1. Coefficient of determination and apparent infection rate of Alfalfa Dwarf Virus of twelve alfalfa cultivars. Cochabamba, Bolivia.

\begin{tabular}{|l|r|r|}
\hline \multicolumn{1}{|c|}{ Cultivar } & \multicolumn{1}{c|}{$\begin{array}{c}\text { R2 } \\
\text { (Coeff.) }\end{array}$} & \multicolumn{1}{c|}{$\begin{array}{c}\text { r } \\
\text { (r/day) }\end{array}$} \\
\hline Condor & 0.9789 & 0.072 \\
Gilboa & 0.9930 & 0.083 \\
Moapa & 0.9947 & 0.084 \\
UMSS 2001 & 0.9798 & 0.084 \\
Monarca & 0.8443 & 0.084 \\
Ranger & 0.9647 & 0.091 \\
Valador & 0.9732 & 0.093 \\
Bolivia 2000 & 0.9893 & 0.094 \\
Jusk'umolle & 0.9622 & 0.094 \\
Africana & 0.9927 & 0.102 \\
Altiplano & 0.9927 & 0.112 \\
Tamborada & 0.9954 & 0.113 \\
\hline
\end{tabular}



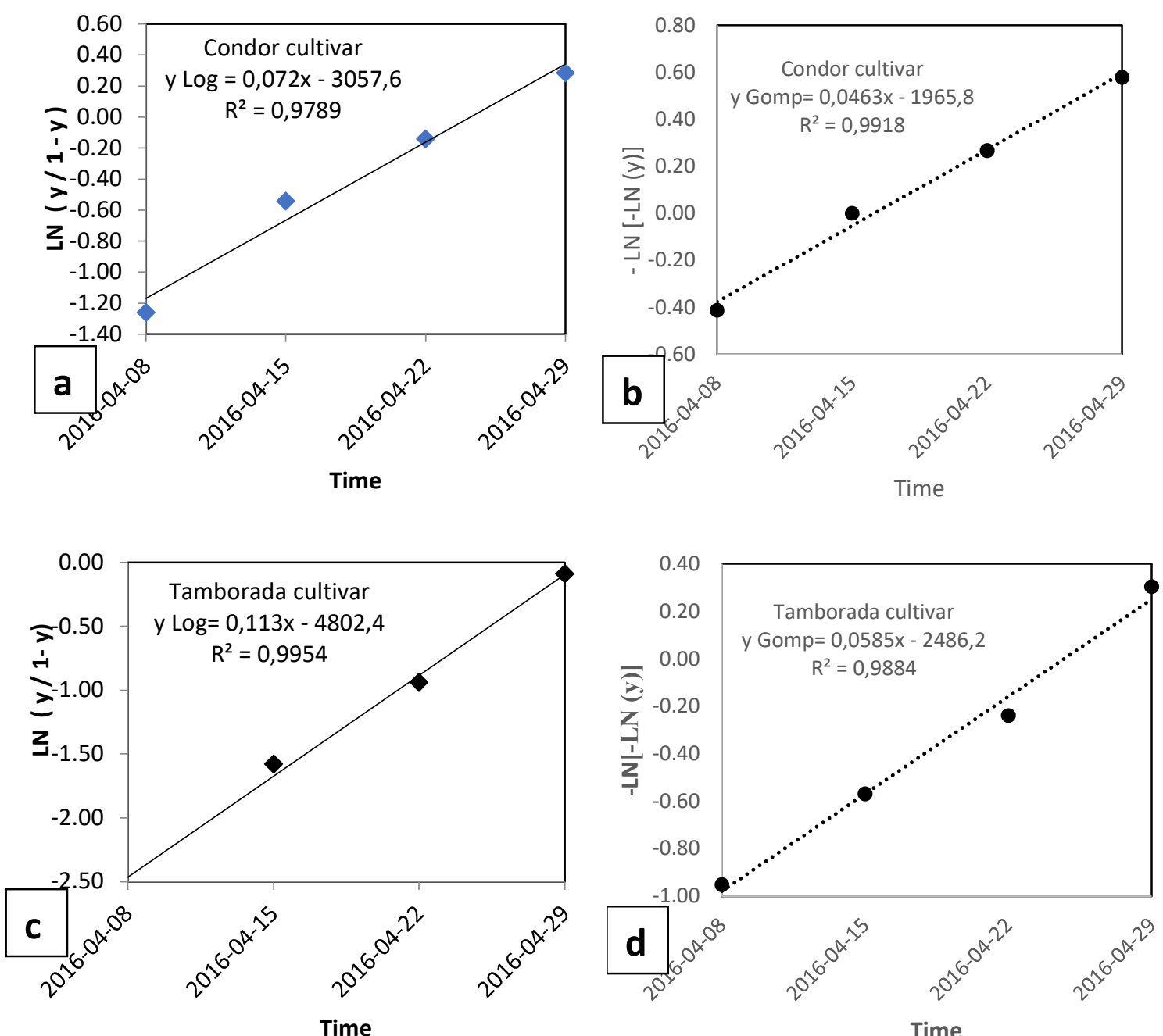

Figure 3: Disease Progress Curve Linearization. a. Condor cultivar linearized with Logistic equation; b. Condor cultivar linearized with Gompertz equation; c. Tamborada cultivar linearized with Logistic equation; d. Tamborada cultivar linearized with Gompertz equation. Lower infection rate (Condor cultivar) and High infection rate (Tamborada cultivar). Cochabamba, Bolivia.

In the upper end of Table 1 (gray color) the Condor (0.072 / day) and Gilboa (0.083 / day) cultivars the lowest rates are found and in the lower end the Africana (0.102 / day), Altiplano (0.112 / day) and Tamborada (0.113 / day) cultivars the highest apparent infection rates. The apparent infection rate estimates the average rate of disease increase over time $[15,16]$. According to the obtained results, in 28 days approximately, the viral disease reaches 0.072 to 0.113 /day rates. By the obtained infection rates, they suggest that the disease viral has a polycyclic character [16]. On the other hand, according to Madden et al. (2007), infection rates are also having a probable relation with the plant genetic resistance because is related with disease quantity (y) too [15]. Thus, it can be suggested the probable genetic resistance degrees in the evaluated cultivars, especially in the Cóndor, Gilboa, Moapa, UMSS 2001 and Monarca cultivars are higher, and lower resistance in the Altiplano, Africana and Tamborada cultivars (Table 1) (Fig. 3). 


\subsection{Dry matter yield $\left(t . h a^{-1}\right)$}

Cultivars show different yield levels in dry matter (Fig. 4a). There is statistical difference (0.05) between Condor (2,29 t.h $\left.{ }^{-1}\right)$ vs. Tamborada (2,65 t.ha-1), Jusk'uMolle $(2,81$ t.ha $\left.{ }^{-1}\right)$ and Altiplano $\left(2,83\right.$ t.ha $\left.^{-1}\right)$ cultivars. Comparing this data to 1997 yields with Lazarte and Delgadillo [4] obtained, a yield reduction in all varieties is observed ranging between 3 to $11 \%$. Apparently alfalfa cultivars viral infection in could be causing reduction in yield dry matter. However, seed transmission of Argentine Alfalfa Virus-AAV and Alfalfa Dwarf Disease-ADD evaluated by Trucco et al (2018) was recorded only for Alfalfa Mosaic VirusAMV (3.75\%); thus, no seed transmission of ADD was observed. Therefore, the viral disease ADD presence in Bolivia is still a subject of wide discussion. By other hand, there are a negative correlation between dry matter and AUDPC is demonstrated, i.e., at higher AUDPC dry matter decreases (Fig. 4b).

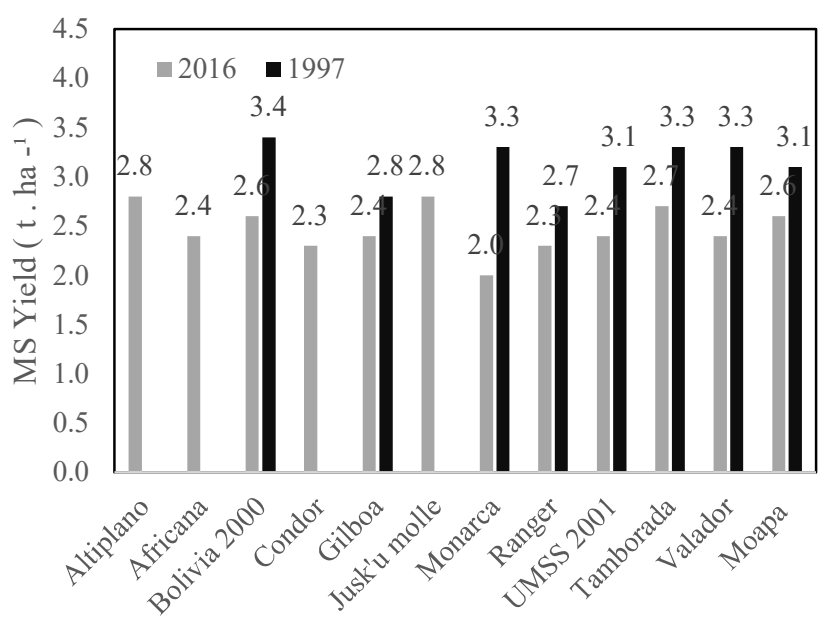

Varieties

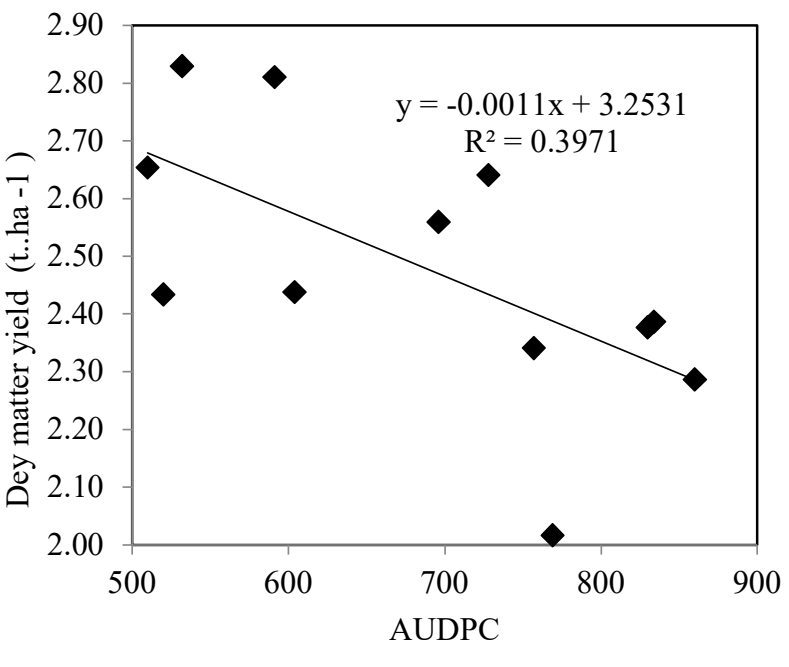

Figure 4: a: Dry matter yield of twelve alfalfa cultivars. Cochabamba, Bolivia, compared with result yield in 1997 (Lazarte y Delgadillo 1997); b: Dry matter yield and AUDPC correlation in twelve alfalfa cultivars. Cochabamba, Bolivia.

\section{Discussion}

Authors should discuss the results and how they can be interpreted from the perspective of previous studies and of the working hypotheses. The findings and their implications should be discussed in the broadest context possible. Future research directions may also be highlighted.

\section{Conclusions}

In conclusion, based on the foliar symptoms registered, the viral disease is associated with the Alfalfa Dwarf Virus and the twelve cultivars evaluated presented different incidence levels of the viral disease and, on the base of this results this viral disease could have an impact on yields to all alfalfa varieties of grown in Bolivia.

Author Contributions: For research articles with several authors, a short paragraph specifying their individual contributions must be provided. The following statements should be used "Conceptualization, M.C.M. and R.M.A.; methodology, R.M.A., N.A.M. and A.C.L.; investigation, R.M.A., N.A.M. and A.C.L.; data curation, M.C.M. and N.A.M.; writing - original draft preparation, M.C.M.; writing - review and editing, R.M.A., M.C.M. and N.A.M.; visualization, X.X.; supervision, M.C.M., 
R.M.A. and N.A.M.; funding acquisition, M.C.M., R.M.A. and N.A.M. All authors have read and agreed to the published version of the manuscript.".

Funding: Please add: “This research received no external funding".

Acknowledgements: The authors wish to express their gratitude to the leguminous program workers of the Research Center Forage (CIF-UMSS, Cochabamba, Bolivia) for the maintenance of the field experiment.

Conflicts of Interest: The authors declare no conflict of interest."

\section{References}

1. Achá N., Espinoza J., Humérez M., Meneses R. 2010. Seguimiento productivo de variedades de Alfalfa (Medicago sativa L.) en "La Violeta". Centro de Investigación en Forrajes "La Violeta". Universidad Mayor de San Simón, Facultad de Ciencias Agrícolas, Pecuarias, Forestales y Veterinarias “Martín Cárdenas”, Departamento de Fitotecnia. Revista Forrajes y Semillas Forrajeras, volumen 12. Cochabamba, Bolivia. 12:95-100.

2. Estación Experimental Belén. 1952. Informe técnico Leguminosas.

3. Fuentes G. y Delgadillo J. 1979. Comparación de diez variedades de alfalfa (Medicago sativa). Pp: 9-14. En: Experiencias en Cultivos forrajeros II. Centro de Investigación en Forrajes "La Violeta”. Universidad Mayor de San Simón. Facultad de Ciencias Agrícolas y Pecuarias. Cooperación Técnica del Gobierno Suizo (COTESU). Empresa Universitaria Productora y Valorizadora de Semillas Forrajeras (SEFO-UMSS). Cochabamba, Bolivia. 89pp.

4. Lazarte L. y Delgadillo J. 1997. Evaluación de 22 cultivares de alfalfa (Medicago sativa) en el Valle de Cochabamba. Revista de Agricultura. (Bolivia). 52 (27): 21-25.

5. Coca-Morante M. 2012. Enfermedades emergentes de la alfalfa causadas por hongos. Editorial Kipus. Cochabamba, Bolivia. $34 \mathrm{p}$.

6. Otazu V., Brown M, Quitón H. 1984. Enfermedades de las plantas en Bolivia. Ministerio de Asuntos Campesinos y Agropecuarios, Instituto de Tecnología Agropecuaria, Consorcio Internacional para el Desarrollo. Cochabamba, Bolivia. $31 \mathrm{p}$.

7. Samac A., Rhodes H., Lamp O. (eds.) 2015. Compendium of alfalfa diseases and pests. 3 rd ed. APS Press. St. Paul. MN.

8. INTA-Informa. 2010. Descubren una nueva enfermedad en alfalfa. https://intainforma.inta.gob.ar/descubren-unanueva-enfermedad-en-alfalfa/. Accessed August 08, 2021.

9. Trucco, V.M., Bejerman, N., de Breuil, S., Cabrera Mederos, D., Lenardon, S., Giolitti, F. 2018. Alfalfa dwarf disease, a viral complex affecting alfalfa crop in Argentina. IN Proceedings. Second World Alfalfa Congress, Cordoba, Argentina. 11-14 November, 2018. Instituto Nacional de Tecnología Agropecuaria (INTA), http://www.worldalfalfacongress.org/

10. Odorizzi A., Cornacchione V., Arolfo V., Basigalup H., Mijoevich L., Balzarini M. 2017. Evaluación de la virosis del achaparramiento de la alfalfa (Medicago sativa L.) en dos ambientes contrastantes de Argentina. AGRISCIENTIA, 34 (II): 69- 81. DOI: $\underline{10.31047 / 1668.298 x . v 34 . n 2.19042}$

11. Bejerman, N., Nome, C., Giolitti, F., Kitajima, E., de Breuil, S., Pérez Fernández, J., D. Basigalup, ; M. Cornacchione and S. Lenardon (2011). First Report of a Rhabdovirus Infecting Alfalfa in Argentina. Plant Disease, 95(6), 771-771. doi: 10.1094/PDIS-10-10-0764

12. Gaafar Yahya Z. A., Richert-Pöggeler Katja R., Christina Maaß , Vetten Heinrich-Josef and Ziebell Heiko. 2019. Characterisation of a novel nucleorhabdovirus infecting alfalfa (Medicago sativa). Virology Journal 16:55 https://doi.org/10.1186/s12985-019-1147-3

13. Rojas Maria R. and Gilbertson Robert L. (2008) Emerging Plant Viruses: a Diversity of Mechanisms and Opportunities. Pp:27-51. In: M. J. Roossinck (Ed.) Plant Virus Evolution. Springer-Verlag Berlin Heidelberg. 223 pp. 
14. Campbell L., Madden V. 1990. Introduction to Plant Disease Epidemiology. John Wiley \& Sons. New York, USA. $532 \mathrm{p}$.

15. Nutter Jr. F.W. 1997. Quantifying the temporal dynamics of plant virus epidemics: a review. Crop Protection, Volume 16 Number 7, 603 - 618. PII: SO261-2194(97)00055-O

16. Madden V., Hughes G., van den Bosch F. 2007. The study of plant disease epidemics. The American Phytopathological Society. St. Paul, Minnesota. 421 p.

17. Nutter Jr. F.W. The role of plant disease epidemiology in developing successful integrated disease management programs. Pp: 45-79. In: A. Ciancio \& K. G. Mukerji (eds.), General Concepts in Integrated Pest and Disease Management, DOI: 10.1007/978-1-4020-6061-8 